\title{
HUMAN PAPILLOMAVIRUS INFECTION IN WOMEN FROM CÂMPULUNG AREA, ARGES COUNTY, IN 2018-2019
}

\author{
Ionica Deliu ${ }^{1,{ }^{*}}$, Liviu Petre Opriş ${ }^{1}$, Cristina Petrovici-Daschevici ${ }^{2}$ \\ ${ }^{1}$ University of Piteşti, Faculty of Sciences, Physical Education and Informatics \\ Târgul din Vale Street, no 1, Piteşti, Romania \\ ${ }^{2}$ Câmpulung Municipal Hospital, Dr. Costea Street, no 8, Câmpulung Muscel, Romania
}

Current Trends in

Natural Sciences

\begin{abstract}
Human Papillomavirus (HPV) infections in women can occur from benign disease to malignant growth. These infections are sexually transmitted diseases. We both try to understand the HPV oncogenesis on the cervical epithelia and to prevent the cervical cancer through treatment of precancerous lesions.

So, it is very important the early diagnosis of this disease because of its incidence and its malignancy potential.

The aim of this paper was to establish the incidence of HPV infections in women from Câmpulung area and the distribution of cases according to their age and residence. The diagnosis of HPV disease was established by multiplex PCR. The incidence of HPV infection was $13.57 \%$ (out of 258 patients), the most frequent HPV genotype was type 16. The results were correlated with histopathological diagnosis. Regarding the age and residence distribution, the most cases were occur in women aged $31-40(48.57 \%)$ and in women from rural areas.
\end{abstract}

Keywords: cervical cancer, HPV, oncogenesis

\section{INTRODUCTION}

The relation between several viruses and cancer in humans is an important concern for worldwide medical personnel. Multiple studies show the properties of these viruses that induce the tumor growth, for the elaboration of strategies to reduce the risk of subsequent oncogenesis, although only virus infection is not sufficient for cancer. Both DNA and RNA viruses can cause cancer in human body. Among these viruses are known the human papilloma virus, Epstein-Barr virus, Hepatitis B and $C$ viruses, human herpes virus 8 (Liao, 2006).

Human papillomavirus (HPV) is a major cause of cervical cancer. This is a small DNA virus from Papillomaviridae Family $(52-55 \mathrm{~nm})$, without envelope, that infects mucosal and cutaneous epithelia and causes mostly benign papillomas. There are more than 100 types of human papilloma virus, some subtypes are associated with cervical cancer because induce the cellular proliferation (WHO, 2007).

The papillomaviruses have a double-stranded circular DNA and icosahedral capsid with 72 pentameric capsomers and two structural proteins (L1 and L2). Its DNA encodes almost eight openreading frames (ORFs). The ORF can be divided in three regions: $\mathrm{E}$ (early) region encodes proteins for viral replication E1 - E7, L (late) region encodes the proteins L1 and L2, LCR (long control region) is important in replication and transcription of viral DNA. 
The link between certain types of HPV and the development of cervical cancer is well known and identified through clinical and para-clinical tests. Sexually transmitted HPV types fall into two groups: high risk HPVs $(16,18,31,33,34,35,45,51,52,58,59,68,70$ - especially 16 and 18) and low risk HPVs $(6,11,42,43,44)$.

After HPVs infect the host epithelial cells, it can integrate into host DNA. The E6 proteins affect the transcriptional pathways and inhibit apoptosis, inducing genome instability with E7 proteins, which destabilize centrosomes and cause mitotic defects. In the high risk HPV types, E6 and E7 proteins have been shown to act as oncoproteins (Oh et al., 2004).

Because the early precancerous changes can be detected by Babes-Papanicolau tests and lesions can be treated, the development of cervical cancer can be prevented. In the absence of this screening, the lesions are detected late and the surgical therapy is applied, beyond of chemotherapy and radiation therapy. So it is very important to detect the HPVs infection because malignancy potential. The structure of HPV is a poor immunogen. The role of the human immune system (by IgG and IgA antibodies and appropriate response of $\mathrm{T}$ and $\mathrm{NK}$ cells) is to prevent of persistent infection and to avoid the progression of precancerous lesions (Liao, 2006). The human papillomavirus can change the cytokines level and the balance between signals from inhibitory and activation receptors. In female patients with cervical cancer were detected low levels of NKp30 and NKp46 receptors (Mihăescu, 2001).

The HPV can evade the cytotoxic action of NK cells also by changes of IDO (indoleamine 2,3Dioxygenase) immunosuppressive enzyme (Amador-Molina et al., 2013; Mbongue et al., 2015).

The identification of HPV infections can be done by non-molecular techniques and molecular tests. The cervical cytology by Babes-Papanicolau and histological tests are indirect methods and are associated with the presence of virus (WHO, 2007). Colposcopy and biopsy are used to establish the lesions caused by virus.

HPVs genomes and proteins can be detected by various techniques (southern and northern blots, in situ hybridization, DNA sequencing, PCR methods).

\section{MATERIALS AND METHODS}

The aim of this study was to determine the incidence of HPV infections in women from Câmpulung area, Argeş County, in 2018-2019. The main applied test was Babes-Papanicolau (Pap) cytological test (conventional smear and liquid-based cervical cytology methods). For those patients with suggestive results for HPV infection the PCR test was applied, in order to establish the type of human papillomavirus.

All the 258 patients were examined in Câmpulung Municipal Hospital and the distribution of cases according to age and residence was established, too. Also, the type of human papillomavirus was identified and the results were correlated with histopathological tests. The patients lived in rural or urban areas and had the age between 24 and 65 years.

The patients distribution regarding the age and residence is presented in Table 1, 61.63\% of women derived from rural areas. The most investigated women were 31 - 40 and 41 - 50 years old.

Conventional smear was introduced in 1943 and was widely used to investigate the cervical cells and their changes in precancerous lesions because of low costs. The exfoliated cervical cells were spreaded, fixed and stained on the glass slide.

In the early of 2000s was applied liquid-base cytology (LBC) based on a cell suspension in a monolayer sheet from sampling tool. The LBC method has advantages like a low unsatisfactory rates and increased sensitivity (Jeong et al., 2017, Phaliwong et al., 2018). 
Current Trends in Natural Sciences

Vol. 9, Issue 17, pp. 317-321, 2020

https://doi.org/10.47068/ctns.2020.v9i17.040

Current Trends in Natural Sciences (on-line)

Table 1. The distribution of studied cases

\begin{tabular}{|l|c|c|c|}
\hline $\begin{array}{c}\text { Residence/ } \\
\text { Age group }\end{array}$ & Urban areas & Rural areas & Total \\
\hline $\mathbf{2 1}-\mathbf{3 0}$ years & 15 & 19 & 34 \\
\hline $\mathbf{3 1}-\mathbf{4 0}$ years & 30 & 56 & 86 \\
\hline $\mathbf{4 1}-\mathbf{5 0}$ years & 26 & 55 & 81 \\
\hline $\mathbf{5 1}-\mathbf{6 0}$ years & 19 & 24 & 43 \\
\hline $\mathbf{6 1}-\mathbf{7 0}$ years & 9 & 5 & 14 \\
\hline Total & $\mathbf{9 9}$ & $\mathbf{1 5 9}$ & $\mathbf{2 5 8}$ \\
\hline
\end{tabular}

The link between HPV and human cervical cancer was the impulse for development of multiple molecular methods to detect HPV infections (Tsakogiannis et al., 2015). The multiplex PCR is a conceptually simple, sensitive and highly specific method, easy to apply in laboratory.

The possibility of viral DNA integration in host DNA and the characteristic genes of certain high risk types of HPV (for instance the E2 and E6) are established by multiplex PCR (Canadas et al., 2009).

\section{RESULTS AND DISCUSSIONS}

The aim of this study was to establish the incidence of HPV infections in women. Among 258 studied cases, 35 presented cytological changes (by Babeş-Papanicolau tests) and HPV infections (by multiplex PCR). The incidence of HPV infections was $13.57 \%$ for tested patients (Figure 1). The HPV infections were determined by one, two or even three types of human papillomaviruses.

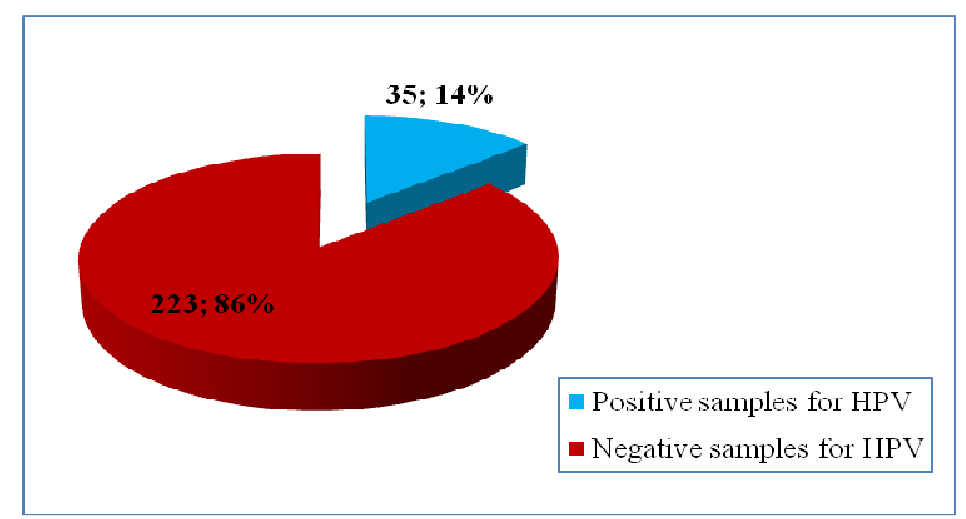

Figure 1. The incidence of HPV infections in studied group

Regarding the age distribution of cases, the situation is presented in Figure 2, the incidence of HPV infections was $19.76 \%$ for the age group $31-40$ years and $13.58 \%$ for the age group $41-50$ years, more than the total incidence for studied group. The lowest incidence was $5.88 \%$, for the age group 21 - 30 years.

The type 16 of HPV (high risk type) was frequent in 31 - 40 and 41 - 50 years patients (Table 2), because the HPV infections are frequent in young women $(48.57 \%$, respective $31.42 \%$ from total positive cases). Some studies reveal the HPV infection is common transient in women less than 21 years. The type 39 of HPV was frequent, too.

Regarding the affiliation of high risk or low risk to determine the cervical cancer, types 16 and 18 are considered with the highest risk in oncogenesis. If the type 16 was present in 23 female patients (alone or with other types) the type 18 was present just in two cases. 


\section{Current Trends in Natural Sciences}

Vol. 9, Issue 17, pp. 317-321, 2020

https://doi.org/10.47068/ctns.2020.v9i17.040

Current Trends in Natural Sciences (on-line)

ISSN: 2284-953X

Current Trends in Natural Sciences (CD-Rom)

ISSN: 2284-9521

ISSN-L: 2284-9521

ISSN-L: $2284-9521$

The results of multiplex PCR were correlated with histological tests (mild to severe dysplasia) and just one case was confirmed with cervical cancer (infected with type 18 of HPV).

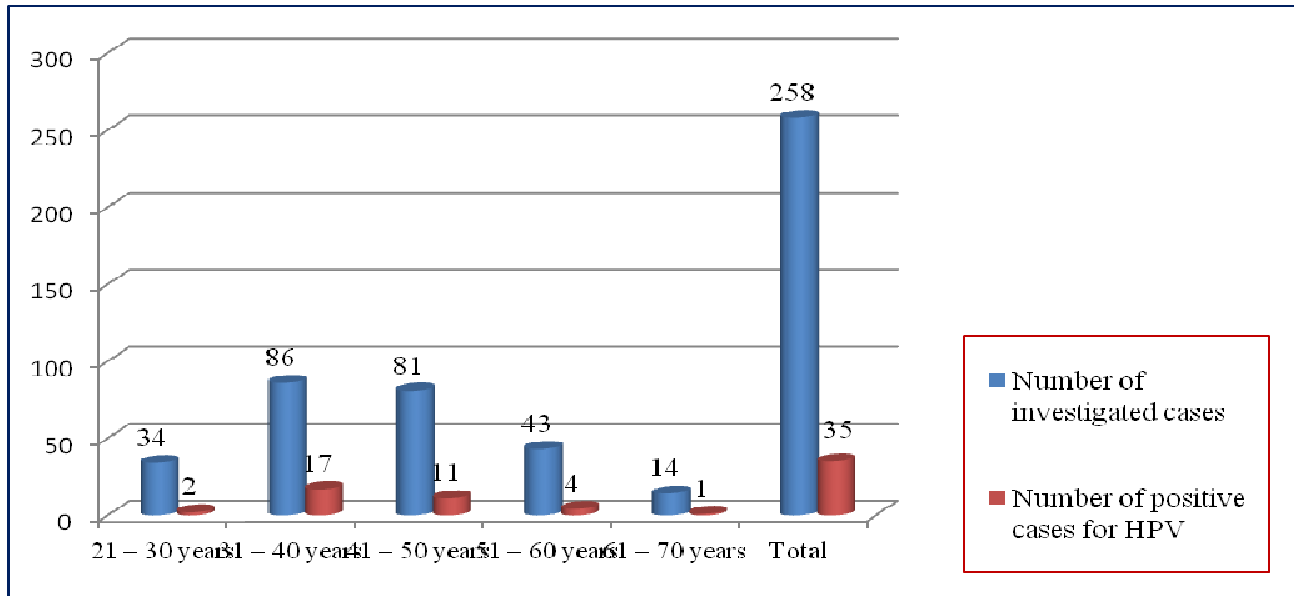

Figure 2. The distribution of HPV infections in studied group, according to patient age

Table 2. Type of HPV according to patient age

\begin{tabular}{|c|c|c|c|c|c|c|c|c|c|c|c|}
\hline \multicolumn{10}{|c|}{ Types of HPV } & \\
Age group & 16 & 18 & 33 & 39 & 16,39 & 16,51 & 16,45 & 18,51 & 39,56 & $16,31,39$ & Total \\
\hline $21-30$ years & & & & 1 & & & & & 1 & & $\mathbf{2}$ \\
\hline $31-40$ years & 11 & & 1 & 3 & 1 & & & & & 1 & $\mathbf{1 7}$ \\
\hline $41-50$ years & 4 & 1 & & 3 & & 1 & 1 & 1 & & & $\mathbf{1 1}$ \\
\hline $51-60$ years & 2 & & & 1 & 1 & & & & & & $\mathbf{4}$ \\
\hline $61-70$ years & 1 & & & & & & & & & & $\mathbf{1}$ \\
\hline Total & $\mathbf{1 8}$ & $\mathbf{1}$ & $\mathbf{1}$ & $\mathbf{8}$ & $\mathbf{2}$ & $\mathbf{1}$ & $\mathbf{1}$ & $\mathbf{1}$ & $\mathbf{1}$ & $\mathbf{1}$ & $\mathbf{3 5}$ \\
\hline
\end{tabular}

The distribution of positive cases for HPV according to residence of patients is presented in Figure 3. Out of 35 positive cases for HPV, $23(65.71 \%)$ were from rural areas. The women from rural areas were more than the women from urban areas in studied cases group, too. The HPV type 16 infections were frequent in women with rural residence.

Some infections with HPV were determined by more than one type of human papillomavirus (Figure 4). Many infections were caused by single type of virus $(80 \%)$, but $17 \%$ of cases were infections with two types of HPV and one case with three types simultaneous.

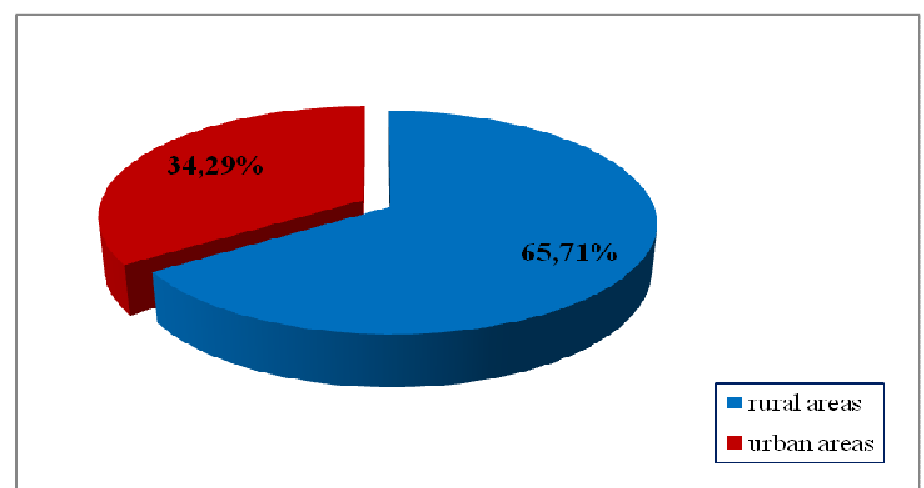

Figure 3. The distribution of HPV infections in studied group, according to patient residence 


\section{Current Trends in Natural Sciences}

Vol. 9, Issue 17, pp. 317-321, 2020

https://doi.org/10.47068/ctns.2020.v9i17.040

Current Trends in Natural Sciences (on-line)

ISSN: 2284-953X

Current Trends in Natural Sciences (CD-Rom)

ISSN: 2284-9521

ISSN-L: 2284-9521

ISSN-L: 2284-9521

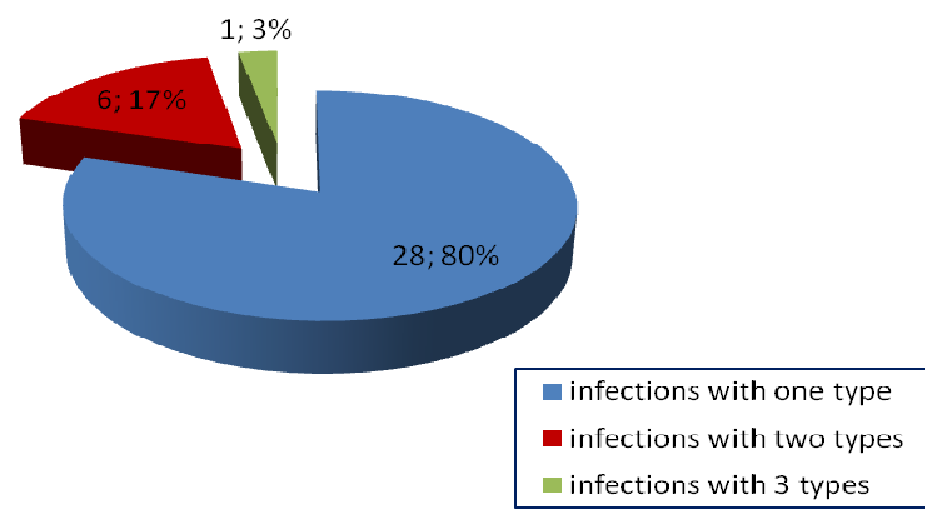

Figure 4. Balance of infections with one or more types of HPVs

\section{CONCLUSIONS}

The incidence of HPV infections in studied group was $13.57 \%$. The most affected age groups were 31 - 40 years $(48.57 \%)$ and 41 - 50 years $(31.42 \%)$, other groups presented just a few cases of HPV infection.

The most cases of infections $(65.71 \%)$ were in women with residence in rural areas and the most frequent type of virus was HPV-16, as single pathogen (80\% of cases) or with other types of human papillomaviruses.

The detection of HPV type from genital infections can contribute to an efficient treatment of precancerous lesions at that level.

\section{REFERENCES}

Amador-Molina, A., Hernandez-Valencia, J.F., Lamoyi, E., Contreras-Paredes, A., Lizano, M. (2013). Role of Innate Immunity against Human Papillomaviruses (HPV) Infections and Effect of Adjuvants in Promoting Specific Immune Response. Viruses, 5(11), 2624 - 2642.

Canadas, M.P., Darwich, L., Sierra, G., Cirigliano, V., Bafill, M., Clotet, B., Videla, S. (2010). New molecular method for the detection of human papillomavirus type 16 integration. European Society of Clinical Microbiology and Infectious Diseases, CMI, 16, 836-842.

Jeong, H., Hong, S.R., Chae, S.W., Jin, S.Y., Yoon, H.K., Lee, J., Kim, E.K., Ha, S.T., Kim, S.N., Park, E.J., Jung, J.J., Sung, S.H., Lim, S.C. (2017). Comparison of Unsatisfactory Samples from Conventional Smear versus LiquidBased Cytology in Uterine Cervical Cancer Screening Test. Journal of Pathology and Translational Medicine, $51,314-319$.

Liao, J.B. (2006). Cancer mechanisms. Viruses and Human Cancer. Yale Journal of Biology and Medicine 79, 115-122.

Mbongue, J.C., Nicholas, D.A., Torrez, T.W., Kim, N.S., Firek, A.F, Langridge, W.H.R. (2015). The role of indoleamine 2,3-Dioxygenase in immune suppression and autoimmunity. Vaccines (Basel), 3(3), 703-729.

Mihăescu, G. (2001). Imunologie şi Imunochimie [Immunology and Immunochemistry], Ed. Universității București, Bucureşti.

Oh, S.T., Longworth, M.S., Laimins, L.A. (2004). Roles of the E6 and E7 proteins in the life cycle of low-risk human papillomavirus type 11. Journal of Virology, 78(5), 2620-2626.

Phaliwong, P., Pariyawateekul, P., Khuakoonratt, N., Sirichai, W., Bhamarapravatana, K., Suwannarurk, K. (2018). Cervical Cancer Detection between Conventional and Liquid Based Cervical Cytology: a 6-Year Experience in Northern Bangkok Thailand. Asian Pac J Cancer Prev, 19 (5), 1331-1336.

Tsakogiannis, D., Diamantidou, V., Taska, E., Kyriakopoulou, Z., Dimitrou, T.G., Ruether, I.G., Gartsilas, P., Markoulatos, P. (2015). Multiplex PCR assay for the rapid identification of human papillomavirus genotypes 16, 18, 45, 35, 66, 33, 51, 58, and 31 in clinical samples. Arch Virol., 160(1), 207-214.

***WHO (2007). IARC Monographs on the Evaluation of Carcinogenic Risks to Humans, Vol. 90, Human Papillomaviruses, Lyon, France. 